\title{
Hydrolysis of Glucose from Bamboo with Micro Controller PID type Arduino UNO and Fuzzy Method
}

\author{
Ni Ketut Sari ${ }^{1}$, Dira Ernawati ${ }^{2}$, Intan Yuniar Purbasari ${ }^{3}$, Basuki Rahmat ${ }^{4}$ \\ ${ }^{1}$ Department of Chemical Engineering, ${ }^{2}$ Department of Industrial Engineering, ${ }^{3,4}$ Department of Informatics \\ Universitas Pembangunan Nasional "Veteran" Jawa Timur \\ Surabaya, Indonesia \\ ${ }^{1}$ ketutsari.tk@upnjatim.ac.id
}

\begin{abstract}
Glucose needs each year has increased significantly while glucose production has decreased, this is because supplies of the raw materials limited, where bamboo is one of the raw material alternatives to glucose. The selection of bamboo plants based on levels of cellulose which ranges from 42.4\% -53.6\%, bamboo plants are plants that can grow quickly and easily grown in various regions in Indonesia. The production of glucose from bamboo using hydrolysis and pretreatment process, in the hydrolysis process of the microcontroller equipped Proportional Integral Derivative (PID) type Arduino UNO, the application of microcontrollers PID using the Fuzzy method and simulation language Delphi programming. Research results in the form of the temperature profile, levels of cellulose hydrolysis time function, and the function time of the hydrolysis of glucose levels. At the time of the detailed set point temperature profile $97^{\circ} \mathrm{C}$, at an early stage shows the result of the PID process control with fault temperature below ten ${ }^{0} \mathrm{C}$, the temperature as measured 94,696 ${ }^{0} \mathrm{C}$, hydrolysis time 20 seconds. As time went on the hydrolysis process control, PID shows the temperature measured is 96.59 ${ }^{0} \mathrm{C}$, at 137 seconds, measured temperature shows $97^{\circ} \mathrm{C}$ following the temperature set point, used as a basis to design tools in the process of hydrolysis. Optimization of cellulose levels function hydrolysis time is $18.7 \%$ and the optimization of the hydrolysis time function of glucose levels is $23,6 \%$. Process design with the production of glucose from bamboo with hydrolysis equipped microcontroller control PID temperature obtained the optimum levels of glucose.
\end{abstract}

Keywords-arduino; fuzzy method; glucose; hydrolysis

\section{INTRODUCTION}

Bamboo is one of the materials containing cellulose is quite high and used when the process of hydrolysis of bamboo that does not include lignin and pentose previously done the method of pretreatment and not lignin. The process used is the best process of biological or chemical means to optimize the production of glucose. On the process of hydrolysis produces glucose levels with $23.6 \%$ of the weight of the bamboo [1]. The output of glucose from lignocellulose depend on the process of pretreatment, chemical, enzymatic hydrolysis. The proper pretreatment is to use acid, alkaline, hydrogen peroxide, bursts of steam, steam, ammonia fiber expansion
[2], Sodium chloride [3], dilute sulfuric acid in removing hemicellulose fraction of substrate lignocellulose [4].

Pretreatment is a significant and critical as one step in a process that is effective in the process of converting biomass into glucose, making it a potential to be developed to be more efficient and economical. Pretreatment is intended to enhance the capabilities of the surface area (porosity) cellulose so that it can increase the conversion of cellulose into glucose. Pretreatment is required to remove the lignin and hemicellulose, cellulose crystals level decreases, thereby increasing the fraction cellulose, and increases the porosity of the material [5].

Availability of starch (liquid waste rice flour) and cellulose (bulrush and bamboo) are available in substantial quantities in Indonesia. Hydrolysis is a process for the breakdown of cellulose into glucose; it is a raw material which gets less attention after raw material analysis have starch, cellulose and glucose levels, have potential as glucose feedstock. The Bamboos used in the hydrolysis process is those that do not contain lignin and pentose that previously performed pretreatment and not lignin process. This research is to produce glucose as a feedstock for bioethanol, knowing pentose and impurities remaining in bamboo solution. This study has the objective to provide glucose and glucose as well as an industrial prototype as a reference in developing bioethanol industry in Indonesia. It needs to study in the future, what is the best process that we can use, biology process or chemical process using $\mathrm{Na}-\mathrm{OH}, \mathrm{H}-\mathrm{Cl}$, and $\mathrm{H}_{2} \mathrm{SO}_{4}$ that can optimize glucose production. The enzyme treatment is also significant because the enzyme has an optimal condition, temperature and the degree of acidity $(\mathrm{pH})$ and when the yeast is in optimal conditions, it can increase its work rate. The comparison obtained can be used as a basis for the design of a prototype glucose production processes and equipment. Resulting from not lignin and hydrolysis process are glucose, liquid waste rice flour on $9.98 \%$ glucose contain, bulrush on $37.9 \%$ glucose contain, and bamboo on $23.6 \%$ glucose include [6].

Bamboo contains cellulose and high glucose, reduce the amount of lignin and pentose pretreatment process and not lignin, filtrate glucose produced in the fermentation using 
enzymes. From the process of fermentation obtained bioethanol with (18-22)\% [7]. The production of glucose in simulations with hydrolysis using the Mat-lab programming language, which in appearance of the graphs the results using the Exell tool, less effective and efficient, so for the visualization needed programming languages objectoriented, in addition to natural developed at, the other has the advantage in a software project can use various programming languages that support object-oriented programming [8].

PID controllers used for motor control applications because of its simple structure and control algorithms are easy to understand. The parameters of the controllers generally use steady-state error, frequency response method or Ziegler-Nichols. This method has a successful outcome but quite a long time and to get a satisfactory system response. Intelligent control-based Artificial Intelligent (AI) has been developed to improve the conventional controls. Design of DC motor control model using some kinds of powers, the PID control tuning with auto-tuning PID mat-lab, which tuning with Ant Colony Optimization (ACO) to control the speed of a DC motor, is expected to have steady state error, settling time and overshoot. Performance results in the model DC motor speed control using Ant Colony Optimization PID (PID-ACO) were found to have faults steady state, continuous and overshoot time better than PID Auto-tuning Mat-lab, the Ziegler Nichols PID (PID-ZN). The result of the PID-ACO programs in this study is the best controller with the fastest time of about 0.55 seconds and overshot the smallest 1.017 [9].

A suitable control system has resistance to disturbance and responds quick and accurate. An Integral Proportional control system on Derivative (PID) when made very sensitive, then the system response against disturbance produces mostly undershot/overshot, so the higher oscillation occurs. In PID control system with fuzzy logic to minimize overshoot and undershot/recovery time from the system response. Fuzzy logic control system designed with two input IE error and delta errors and output speed of the motor. A significant output of the fuzzy logic control system is only $50 \%$ of PID control. From the design of the system is expected in the overall control system which is a hybrid between PID Control with Fuzzy logic can produce a better system response [10].

The production of glucose from bamboo is experimental research furnished the application technology of the fuzzy control the Arduino UNO types in temperature.

\section{APPLICATION OF PID IN THE PROCESS HYDROLYSIS}

Application technology of microcontroller PID temperature type of Arduino UNO for the production of glucose from bamboo by hydrolysis to obtain temperature profiles against hydrolysis time retrieved precise and accurate results. With this application, it will be extracted the right temperature range, during the process of hydrolysis of the already determined the temperature set point, temperature control with easy tools in the design process of hydrolysis.

\section{A. Proportional Integral Derivative (PID)}

PID controllers used for motor control applications because of its simple structure and control algorithms are easy to understand. The parameters of the controllers generally use Try and Error frequency response method or Ziegler-Nichols. This method has a successful outcome but quite a long time and to get a satisfactory system response. Intelligent controlbased Artificial Intelligent (AI) has been developed to improve the conventional controls. Design of DC motor control model using some kinds of powers, i.e., the PID control tuning with mat-lab, the PID auto-tuning with Ant Colony Optimization (ACO) to control the speed of a DC motor, is expected to have steady state error, settling time and overshoot. DC motor output routed to invert input PID which further calculate substantial difference or mistake that is later used to improve PID constants.

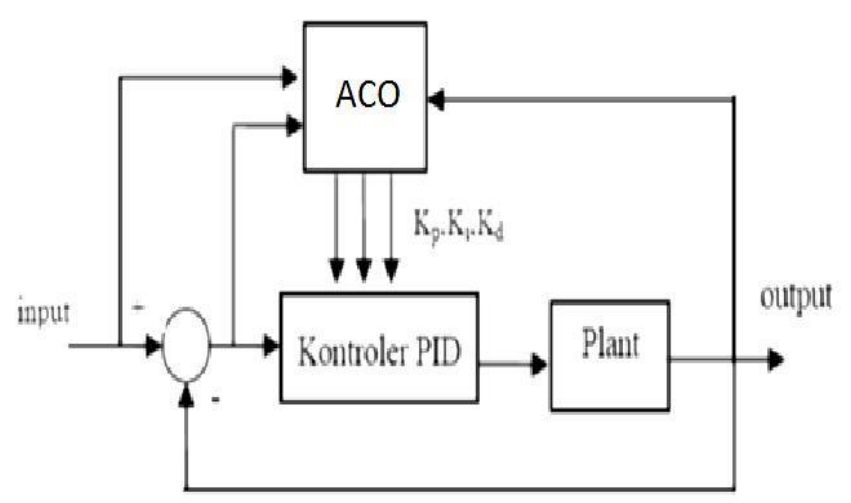

Fig. 1. Controller PID-ACO for plant

PID control is a composite control system between the proportional control, integral, and derivative, the application of this method in a closed system, where the reference input function is a ladder (step). Controllers used proportional controllers $(\mathrm{Kp})$, raised from 0 to a critical value of proportional controllers, so gained output that continually oscillates with the same amplitude, critical appraisals of proportional controllers called ultimate gain. The amount of the final period, obtained after the production of the system achieve continuous oscillation conditions.

Common characteristics used in the control of such a system include the stability, accuracy, speed of response and sensitivity [11]. Proportional control in action, the output of the control system necessarily proportional to its input. The output signal is the strengthening of a signal fault with specific factors, and it is strengthening proportional factor and constant of the system, which expressed with a factor proportional, where factor proportional has a high response/quick. Integral control in action, the output of the controller is continually changing throughout the deviation, and the speed of change of the production is proportional to error, its constant declared (Ki), where it has a high sensitivity, by way of the reduction of error resulting from the feedback signal. The high the value of $\mathrm{Ki}$ so sensitivity will be higher, but the time required to achieve stability faster, and vice versa. While the action control of the derivative works based on the 
rate of change of the junction, so the type of the controller is always used together with proportional and integral controller, its constant declared (Kd), where it affects the stability of the system, due to the action of this control can reduce errors.

$$
\begin{aligned}
\mathrm{D}=\operatorname{Kpe}(\mathrm{t})+\mathrm{Ki} \int \mathrm{e}(\mathrm{t}) \mathrm{dt}+\mathrm{Kd} \frac{\mathrm{de}(\mathrm{t})}{\mathrm{dt}} \\
P_{\text {Term }}=K p e(t) \\
\mathrm{I}_{\text {Term }}=\operatorname{Kt} \int \mathrm{e}(\mathrm{t}) \mathrm{dt} \\
\mathrm{D}_{\text {Term }}=\operatorname{Kd} \frac{\mathrm{de}(\mathrm{t})}{\mathrm{dt}}
\end{aligned}
$$

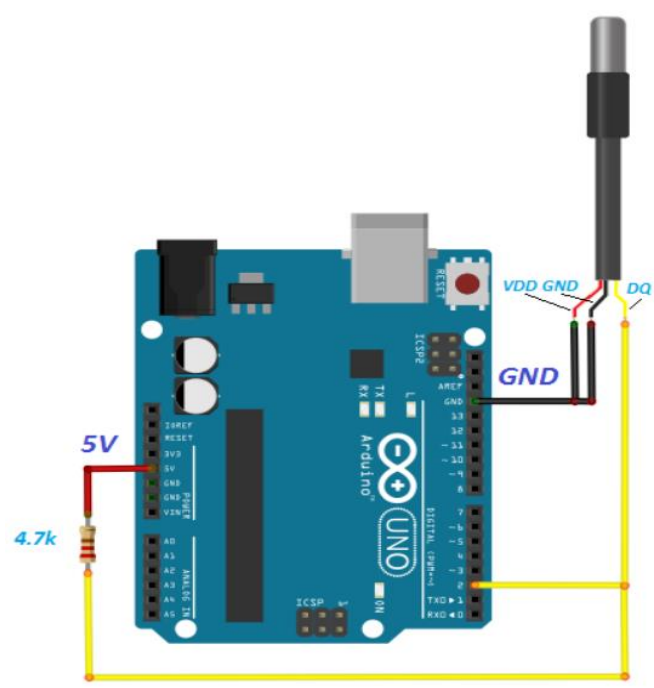

Fig. 2. Configuration hardware of temperature sensor DS18B20

The sensor is a digital sensor DS18B20 has 12-bit internal ADC, high precision with reference voltage of 5 volts, the smallest change in temperature equates 0.0012 volts, in the temperature range -10 to +85 degrees Celsius, sensor DS18B20 has the sensor accuracy is $+/-0.5$ degrees, the sensor works using the 1-wire communication protocol (one-wire).

\section{B. Experiment Process of Hydrolysis.}

The production of glucose from bamboo is experimental research furnished the application technology of the fuzzy control the Arduino UNO types in temperature, with the study as in Fig. 3.

\section{RESULTS AND DISCUSSION}

\section{A. Results of Cellulose and Glucose Hydrolysis Process}

The pieces and refined fiber of bamboo with an approximate length of $5 \mathrm{~cm}$ and polished thread 200 mesh were to obtain the high levels of glucose and cellulose before bacillus, and $\mathrm{H}-\mathrm{Cl}$ solution hydrolyzed it. It should in powder form so that cellulose hydrolyzed perfectly. However, that process took a higher cost. Besides, bulrush in the powder form could suffer the physical destruction, thus causing the damage of the glucose group. The drying process of bulrush

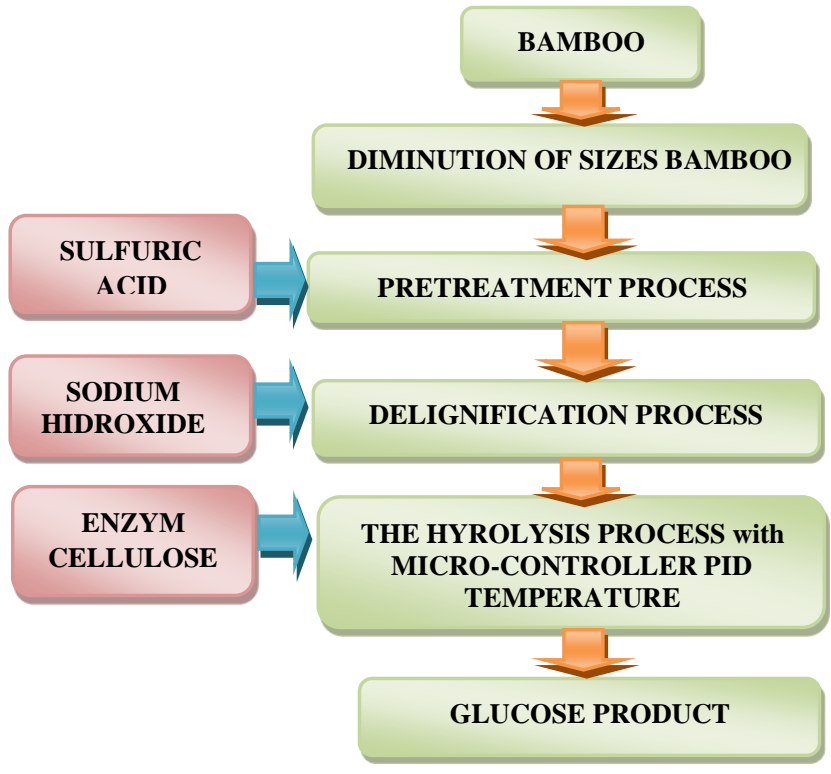

Fig. 3. Block diagram of glucose production from bamboo fitted of the fuzzy control

was naturally done first in the room temperature. The drying process was done in an oven at $100{ }^{\circ} \mathrm{C}$ for 3 hours.

It was for cost savings, and the dryer process aimed to reduce the water content in ethanol. The water level that was permitted by Standart National Indonesia (SNI) was $1 \%$. The decreasing of $\mathrm{pH}$ from pretreatment material was affected by the addition of $\mathrm{H}-\mathrm{Cl}$ volume $7 \% \mathrm{v} / \mathrm{v}$ because the requiring $\mathrm{pH}$ for fermentation process was 4,5. Before doing the hydrolysis process, the $\mathrm{pH}$ of the filtrate measured according to the terms of the fermentation process that is approximately 4.5 , to obtain $\mathrm{pH} 4.5$, the addition of $\mathrm{Na}-\mathrm{OH}$ done if $\mathrm{pH}$ of the filtrate was under 4.5 and the addition of citric acid if the filtrate $\mathrm{pH}$ was above 4.5 .

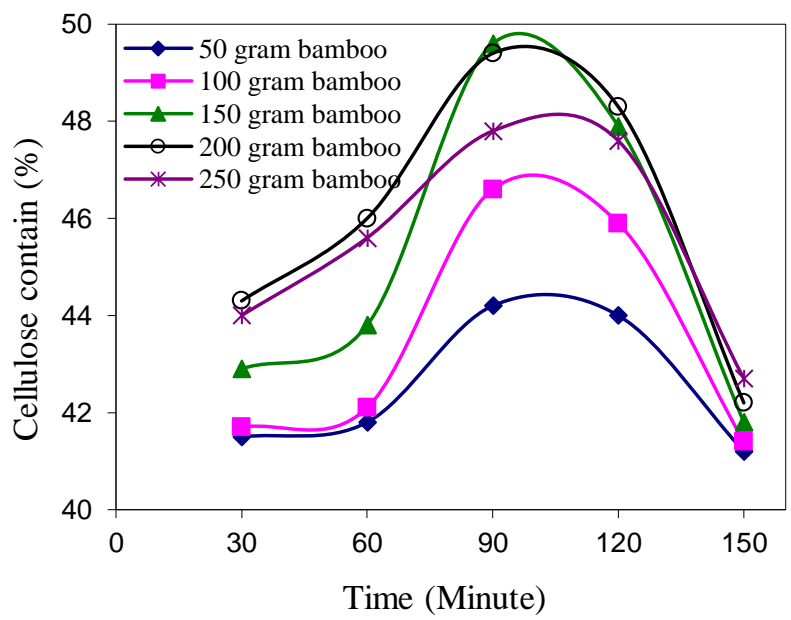

Fig. 4. Contains cellulose function hydrolysis time

In Figure 4 at the time of 90 minutes, $47.8 \%$ cellulose concentration trend at the maximum weight of 150 grams of bamboo. On the research [12], selulose $47.8 \%$ concentration obtained from hard and soft wood. One of the materials that contain cellulose that is bamboo. The percentage of cellulose 
on bamboo i.e., $42.4 \%-53.6 \%$. The percentage of other components contained of bamboo lignin is (19.8\%-26.6\%), pentosan $(1.24 \%-3.77 \%)$, extractive substances $(4.5 \%$ $9.9 \%)$, water $(15 \%-20 \%)$, substance followup (1.24\%$3.77 \%)$, and $\mathrm{SiO} 2(1.78 \%-0.1 \%)$. The percentage of cellulose makes the larger bamboos as one source of bioethanol cellulose [3]

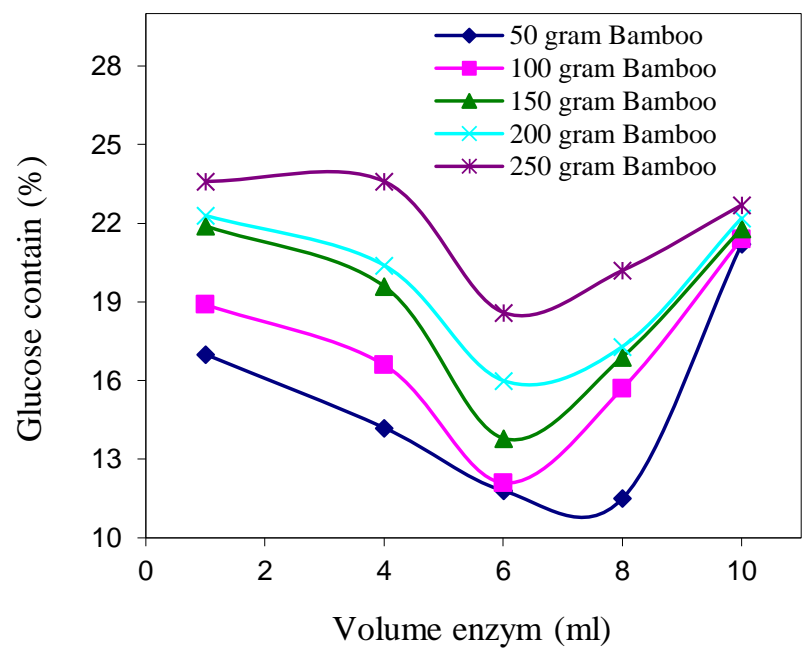

Fig. 5. Contains glucose function volume enzyme

In Figure 5 on a volume of $4 \mathrm{ml}$ enzyme, glucose concentration maximum $23.6 \%$ on trend on large bamboo 250 grams, maximum levels obtained from the cellulose of wood $18.7 \%$. With the results obtained allows the bamboo can be as the raw material alternative to bioethanol. Several factors that encourage research utilization intensive do lignocellulose materials into a source of energy, in this case, ethanol [12]. First, the needs and energy consumption continued to increase from year to year, while natural resources which can generate energy depleted because most of the current sources of energy derived from natural resources that are not renewable, such as oil, gas, and coal. Second, bioethanol has better characteristics compared to gasoline because it can increase the efficiency of combustion [13].

\section{B. Proportional Integral Derivative (PID)}

OMRON's Industrial Temperature Regulator developed hybrid control system of the fuzzy control. Then applied on micro-technology a Proportional Integral Derivative temperature type Arduino on hydrolysis process using the Fuzzy method. The primary system is the control of Fuzzy, whereas fuzzy logic here serves to improve response and recovery time against disturbance as shown in Figure 6. The output of the fuzzy control unit produced has a smaller load of the control of Fuzzy, meaning that range from the output membership function has the set.

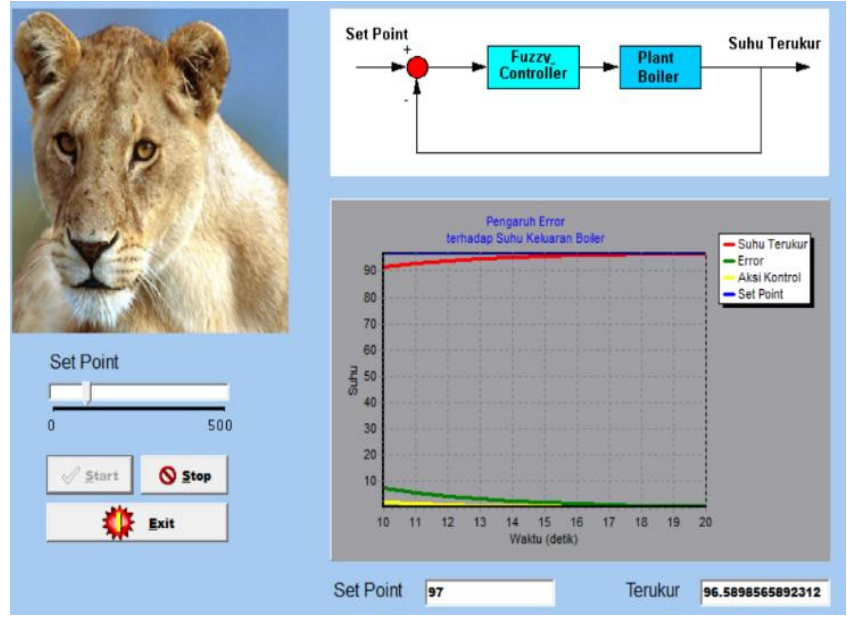

Fig. 6. Temperature profile function of time on the set point $\left(97^{\circ} \mathrm{C}\right)$ and the measured temperature is $94.696{ }^{\circ} \mathrm{C}$.

At the time of 14 seconds, set point $97{ }^{\circ} \mathrm{C}$, the action control and error show the temperature below ten ${ }^{\circ} \mathrm{C}$ and the temperature of the measured $94.696{ }^{\circ} \mathrm{C}$. With the passage of time will be retrieved according to temperature set point, such as a Figure 6. At the time of 20 seconds, the set point $97{ }^{\circ} \mathrm{C}$ shows the action control, and error shows the temperature under $0{ }^{0} \mathrm{C}$ and the measured temperature is $96.59{ }^{0} \mathrm{C}$, with the passage of time will be retrieved according to the temperature set point.

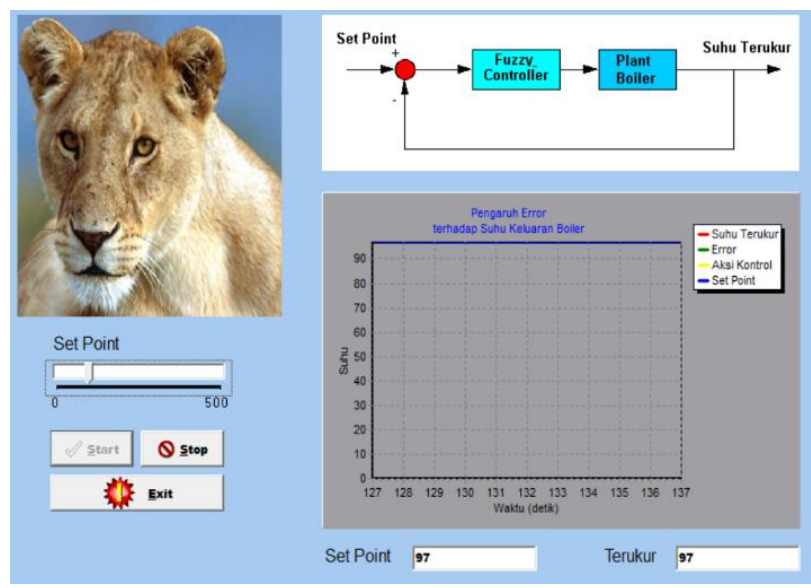

Fig. 7. Temperature profile function of time on the set point $\left(97{ }^{\circ} \mathrm{C}\right)$ and the measured temperature is $97{ }^{\circ} \mathrm{C}$.

At the time of 137 seconds, set point $97{ }^{\circ} \mathrm{C}$ shows the action control and error shows the temperature under $0{ }^{\circ} \mathrm{C}$ and the measured temperature is $97{ }^{0} \mathrm{C}$ as Figure 7. Microtechnology an Integral Proportional temperature Derivative controller type Arduino UNO using the Fuzzy method can use as a reference in the design of the excellent hydrolysis process tools. 


\section{CONCLUSION}

The hybrid control system capable of generating a response and recovery time is better and resistant to disturbance, is evident from the results of testing the system with the awarding of the disorder, an occurrence of undershoot and overshoot of the granting of discharge loads and load can be mute. To get a good response on hybrid PID control system-Fuzzy method can be done tuning evaluation rules as well as the membership function value to widen the way crisp input, with the aim to dampen overshot.

At the time of 137 seconds, set point $97{ }^{\circ} \mathrm{C}$ shows the action control and error shows the temperature under $0^{\circ} \mathrm{C}$ and the measured temperature is $97{ }^{0} \mathrm{C}$. Micro-technology an Integral Proportional temperature Derivative controller type Arduino UNO using the control of Fuzzy, can be used as a reference in the design of the excellent hydrolysis process tools at optimization of the cellulose levels function hydrolysis time is $18.7 \%$, and the optimization of the glucose levels function hydrolysis time is $23.6 \%$.

\section{ACKNOWLEDGMENT}

The authors would like to acknowledge the financial support of the Directorate Research and Public Service. The Directorate of Research and Development Strengthening. The Ministry of Research, Technology, and Higher Education of the Republic of Indonesia with the ResearchBased Competence Grant. Contract Number: 083/SP2H/LT/DRPM/2018.

\section{REFERENCES}

[1] N.K. Sari, Y. Nico, L. Tika, and E. Dira, "Hydrolysis of Cellulose from Bamboo with Biology Process Using Enzyme”, J. Adv. Sci. Lett. , vol. 23, no. 12, pp. 12235-12238, 2017.

[2] F. Teymouri, L.L. Peres, Alizadeh, and B.E. Dale, "Optimization of the Ammonia Fiber Explosion (AFEX) Treatment Parameters for Enzymatic Hydrolysis of Corn Stover", Bio-resour. Tech., vol. 96, pp. 2014-2018, 2005.

[3] A. Kumar, L.K. Singh, and S. Ghose, "Bioconversion of Lignocellulose Fraction of Water-Hyacinth (Eichhornia) Hemicellulose Acid Crassipes Hydrolysate to Ethanol by Pichia Stipilis", Bio-resour. Tech., vol. 100, pp. 3293-3297, 2009.

[4] N.K. Sari, S. Sutiyono, E. Luluk, E. Dira, W. Putu, and S.H. Tatik, "Bioethanol Production from Liquid Waste of Rise Flour with Batch Process", Proc. MATEC Web Conf., vol. 58, no. 01003, pp. 1-5, 2016.

[5] J.S. Lee, B. Parameswaran, J.P. Lee, and S.C. Park, "Recent Development of Crusial Technologies On Cellulosic Ethanol Production", J Sci. Ind. Res vol. 67, no. 11, pp. 965-873, 2008.

[6] N.K. Sari, Pudjiastuti, and Ketut Sumada, Comparison Production Glucose from Starch and Cellulose Using Delignification Hydrolysis Process, vol. 23, no. 12, 2017, pp. 12318-12321.

[7] N.K. Sari and E. Dira, "Comparison Production Bioethanol from Cellulose using Batch Distillation and Flash Distillation Process", J. GEOMATE,vol. 15, no 50, pp. 76-81, 2018.

[8] N.K. Sari, C. Pujiastuti, I. Nyoman Abdi, "Bioethanol Production Comparison of Elephant Grass and Liquid Waste Plant Wheat Boga Sari", Int Semin.Chem. Eng. Bio-Energy, Chem. Mater. (BioEnChe 2013), 2013.
[9] Mochammad Nur Masrukhan, Mochamad Piono Mulyo, Dwi Ajiatmo, and Machrus Ali, Optimization of Speed Motor DC Using PID with Tuning Ant Colony Optimization (ACO) Controller, Proceeding SENTIA ISSN: 2085-2347, Politeknik Negeri Malang, vol. 8, 2016, pp. B-49-B-52.

Mochammad Nur Masrukhan, Mochamad Piono Mulyo, Dwi Ajiatmo dan Machrus Ali, Optimasi Kecepatan Motor Dc Menggunakan Pid Dengan Tuning Ant Colony Optimization (Aco) Controller, Prosiding SENTIA ISSN: 2085-2347, Politeknik Negeri Malang, Volume 8, 2016. hal. B-49 - B-52.

[10] M. Samsul Bachri, Hybrid Control System of PID-Fuzzy Logic on DC Motor Speed Settings, Makara Technology, vol. 8, no. 1, 2004, pp. 2534.

Samsul Bachri M. 2004, Sistem Kendali Hybrid Pid - Logika Fuzzy Pada Pengaturan Kecepatan Motor DC, MAKARA, TEKNOLOGI, VOL. 8, NO. 1, hal. 25-34.

[11] J.M. Jacob, "Industrial Control Electronics Application and Design," Prentice Hall Inc. Englewood Cliffs, New Jersey, 1988.

[12] Nibedita Sarkar, K.G. Sumanta, Satarupa Bannerjee, Kaustav Aikat, Bioethanol Production from Agricultural Wastes: An Overview, Renewable Energy, vol. 37, 2012, pp. 19-27.

[13] A. Limayem and S.C. Ricke, Lignocellulosic Biomass for Bioethanol Production: Current Perspectives, Potential Issues, and Future Prospects, Progress Energy Combust. Sci., vol. 38, 2012, pp. 449-67. 